\title{
ANALISIS FAKTOR YANG MEMPENGARUHI PROSES KLAIM BPJS DI RSUD LEUWILIANG BOGOR TAHUN 2018
}

\author{
Linda Dwi Astuti' ${ }^{1}$, Indira Chotimah ${ }^{2}$, Siti Khodijah Parinduri ${ }^{3}$ \\ ${ }^{1}$ Konsentrasi Manajemen Pelayanan Kesehatan, Program Studi Kesehatan Masyarakat Fakultas Ilmu Kesehatan, \\ Universitas Ibn Khaldun Bogor. Jl. K.H Sholeh Iskandar Raya Km. 2, Kedung Badak, Bogor 16162, Jawa Barat. \\ Email : lindadwiat@gmail.com \\ 2,3Konsentrasi Manajemen Pelayanan Kesehatan, Program Studi Kesehatan Masyarakat Fakultas Ilmu Kesehatan, \\ Universitas Ibn Khaldun Bogor. Jl. K.H Sholeh Iskandar Raya Km. 2, Kedung Badak, Bogor 16162, Jawa Barat.
}

\begin{abstract}
Abstrak
Sejak ditetapkan sistem Jaminan Kesehatan Nasional di Indonesia sejak 2004, rumah sakit diseluruh Indonesia secara bertahap diwajibkan untuk bekerja sama dengan BPJS. Berlakunya sistem ini diharapkan meningkatkan mutu pelayanan kesehatan masyarakat. Namun dalam pelaksanaannya terdapat berbagai kendala yang menyebabkan terganggunya kinerja rumah sakit berkenaan dengan cashflow atau kendali biaya rumah sakit. Salah satu penyebabnya adalah berkas klaim yang diserahkan kepada BPJS tidak sesuai dengan ketentuan klaim sehingga klaim tidak dibayarkan dan menyebabkan kerugian bagi rumah sakit. Tujuan penelitian ini untuk menganalisis gambaran faktor input, proses dan output dari keterlambatan pemprosesan klaim BPJS di RSUD Leuwiliang. Penelitian ini menggunakan metode kualitatif dengan menggunakan pendekatan sistem melalui wawancara mendalam dan observasi. Hasil penelitian dari komponen input terkait jumlah SDM masih kurang, beban kerja yang ganda, pelatihan SDM masih kurang, dimana SIMRS belum berjalan maksimal, tidak adanya dana insentif dan masih terdapat ruangan yang tidak memiliki SOP. proses terkait alur proses klaim sudah berjalan namun masih terdapat kendala dalam penginputan proses klaim antara lain jaringan internet eror, ketidak lengkapan berkas, double berkas, keterlambatan berkas, salah koder, hasil penunjang tidak lengkap, tulisan dokter sulit dibaca. output terdapat selisih berkas yang artinya masih ada dana rumah sakit yang belum dibayarkan dan masih ada yang ditolak oleh BPJS pada rawat jalan yang ditolak sebanyak 1.586 berkas klaim dan rawat inap yang ditolak sebanyak 1.319 berkas klaim. Diharapkan rumah sakit memberikan kesempatan pelatihan kepada seluruh pegawai untuk meningkatkan kinerja pegawai berkenaan dengan sistem BPJS untuk mengoptimalkan pemberkasan, perlunya meningkatkan dan lebih mendayagunakan fungsi SIMRS.
\end{abstract}

Kata Kunci : BPJS, Keterlambatan Klaim, Berkas ditolak.

\section{PENDAHULUAN}

Sistem Jaminan Kesehatan Nasional (JKN) sudah diterapkan di Indonesia sejak tahun 2004 sesuai dengan amanat Undang-Undang Nomor 40 Tahun 2004, ditetapkan untuk mengatasi persoalan dalam bidang kesehatan. Amanat bahwa jaminan sosial wajib bagi seluruh penduduk termasuk JKN melalui suatu Badan Penyelenggara Jaminan Sosial (BPJS) yang ditetapkan dalam Undang-Undang Nomor 24 Tahun 2011 tentang BPJS yang terdiri dari BPJS Kesehatan dan BPJS Ketenagakerjaan. Sebagai tindak lanjut JKN yang diselenggarakan 
oleh BPJS Kesehatan sejak tanggal 1 Januari 2014, dimana secara operasional pelaksanaan JKN di tuangkan dalam Peraturan Pemerintah Nomor 101 Tahun 2012 Tentang Penerima Bantuan Iur (PBI); Peraturan Presiden Nomor 12 Tahun 2013 tentang Roadmap JKN. Berdasarkan Peraturan Menteri Kesehatan No.71 tahun 2013 tentang Pelayanan Kesehatan pada Jaminan Kesehatan Nasional menyebutkan bahwa sistem jaminan kesehatan adalah jaminan berupa perlindungan kesehatan agar peserta memperoleh manfaat pemeliharaan kesehatan dan perlindungan dalam memenuhi kebutuhan dasar kesehatan yang diberikan kepada setiap orang yang telah membayar iuran atau iurannya dibayar oleh pemerintah kesehatan.

Salah satu subsistem yang terdapat dalam sistem kesehatan ialah subsistem pembiayaan, untuk itu dalam rangka memenuhi dengan jelas dan lengkap sistem kesehatan maka perlulah dipahami pula tentang subsistem pembiayaan kesehatan. Namun dalam kenyataan dalam hal ini masih kurang dimengerti dan dipahami sepenuhnya dimana masih terdapat permasalahan antara pelayanan kesehatan yang diterima dengan tuntutan pengajuan klaim dan rumah sakit, yaitu pengajuan klaim tidak sesuai dengan prosedur dan tarif dalam Perjanjian Kerjasama (PKS) sehingga menimbulkan masalah bagi rumah sakit.

sistem adalah kumpulan dari elemen-elemen yang berinteraksi untuk mencapai suatu tujuan tertentu (Jogianto, 2005). Sistem ini menggambarkan suatu kejadian-kejadian dan kesatuan yang nyata, seperti tempat, benda, dan orang-orang yang betul-betul ada dan terjadi. Menurut Azwar Unsur dari suatu sistem antara lain:

1. Masukan (input) adalah sumber daya yang masuk kedalam sistem yang akan diolah untuk menghasilkan sesuatu.

2. Proses (process) atau pengolah sistem adalah bagian dari setiap sistem dan subsistem yang akan mengelolah input sehingga menjadi keluaran (output).

3. Luaran (output) adalah hasil dari apa yang dijalankan oleh proses.

Adapun beberapa contoh sistem pembayaran klaim dari beberapa negara yaitu :

Belanda sudah menggunakan validasi e-klaim sejak 2009 penyedia layanan kesehatan dan pembayar berinteraksi lewat pusat jalur klaim. Secara operasional, standarisasi dan pengolahan elektronik berhasil mengurangi beban administrasi pada sistem, mengurangi kesalahan administratif dan memperpendek masa proses klaim dan pembayaran untuk seluruh spektrum penyedia asuransi kesehatan. Abu Dhabi semua klaim diproses secara elektronik melalui sistem web yang canggih dan terstandarisasi. Jepang belum ada sistem yang efektif dan efisien mengenai klaim dan pembayaran antara organisasi asuransi kesehatan penyedia medis.

Di indonesia, metode pembayaran prospektif telah diterapkan sejak tahun 2008 sebagai metode pembayaran dalam program jaminan kesehatan masyarakat (Jamkesmas). Salah satu metode pembayaran prospektif dikenal dengan nama Casemix (case based payment) yang mengelompokkan diagnosis dan prosedur dengan mengacu pada ciri klinis yang mirip/sama dan penggunaan sumber daya/biaya perawatan yang mirip/sama menggunakan software grouper.

Berdasarkan hasil penelitian yang dilakukan oleh Noviatri di Rumah Sakit Panti Nugroho pada bulan Januari 2016, diketahui bahwa berkas klaim pasien BPJS diserahkan 
kepada verifikator BPJS pada tanggal 15 bulan berikutnya. kemudian hasil verifikasi diserahkan kepada BPJS pada tanggal 17 apabila terjadi keterlambatan penyerahan berkas klaim, maka berkas klaim tersebut akan di pending dan akan diikut sertakan pada proses klaim bulan selanjutnya, hal ini akan berakibat pada menurunnya jumlah hasil klaim yang didapat oleh fasilitas kesehatan pada bulan tersebut.

Penyebab Keterlambatan klaim BPJS dari aspek prosedur pengajuan klaim yaitu terdapat berkas klaim yang belum lengkap serta belum ada prosedur tertulis yang mengatur persyaratan jaminan untuk pasien BPJS. Berdasarkan kelengkapan dokumen kaim pasien rawat jalan dari 99 dokumen terdapat 21 dokumen atau 21,2\% dokumen klaim BPJS yang tidak lengkap dan 78 dokumen atau 78,7\% dokumen sudah lengkap. Penyebab keterlambatan kaim dari aspek kelengkapan persyaratan pengajuan klaim BPJS yaitu terdapat kesalahan pada surat rujukan, tidak adanya tanda tangan dokter dan diagnosa tidak tertulis diformulir bukti pelayanan rawat jalan, dan tidak ada fotocopy.

Berdasarkan hasil penelitian yang dilakukan oleh Anggrainatingai di Rumah Sakit DKT Dr. Soetarto Yoyakarta tahun 2013 bahwa persentase keterlambatan di Rumah Sakit DKT Dr. Soetarto Yogyakarta masih besar angka keterlambatannya meliputi bangsal kartika mencapai 87,2\%, bangsal kirana mencapai 94,9\%, bangsal kebidanan mencapai 61,3\%, bangsal husada mencapai 90,2\% dan bangsal VIP mencapai 100\%. Faktor penyebab keterlambatanya yaitu SDM khususnya pemahaman perawat bangsal mengenai kurangnya sosialisasi prosedur tetap, ketidak lengkapan berkas yang menyebabkan rekam medis yang harus sudah dikembalikan ke instalasi rekam medis belum dikembalikan karena harus melengkapi pengisiannya terlebih dahulu dan tidak adanya kegiatan assembling sehingga tidak adanya petugas khusus yang bertugas mengecek kelengkapan rekam medis pasien.

Semenjak berlakunya Jaminan Kesehatan Nasional (JKN) melalui program BPJS perMaret 2017 sudah ada 2079 rumah sakit bekerja sama dengan BPJS Kesehatan sebagai asuransi kesehatan pemerintah untuk menjamin kesehatan penduduk di Indonesia. Dalam Implementasinya, BPJS kesehatan menggunakan INA-CBGs sebagai standard penetapan biaya sesuai dengan diagnosis yang diberikan rumah sakit. Tarif INA- CBGs saat ini masih dianggap rendah oleh sebagian masyarakat dikarenakan masih banyak rumah sakit yang mematok tarif lebih tinggi disbanding tarif INA-CBGs sehingga terdapat selisih negatif antara tarif INA-CBGs dengan tarif rumah sakit yang pada akhirnya rumah sakit menngalami kerugian.

Dengan adanya perubahan tarif INA-CBGs melalui Peraturan Menteri Kesehatan Nomor 52 tahun 2016 tentang Standar Tarif Pelayanan Kesehatan Dalam Penyelenggaraan Program Jaminan Kesehatan Nasional maka terdapat perubahan klaim tarif INA-CBGs yang berdampak terhadap pengendalian biaya di rumah sakit. Dalam hal ini rumah sakit harus bisa mensiasati dan terus belajar memverifikasi agar tidak terjadi kesalahan dalam memasukan data penyakit maupun tindakan sehingga proses klaim INA-CBGs berjalan lancar.

RSUD Leuwiliang melayani pasien BPJS, dimana secara operasional masih banyak yang harus dilakukan penyesuaian terhadap sistem di era JKN ini. Salah satunya adalah terkait kelengkapan berkas klaim pasien BPJS. Era sekarang ini melalui program JKN oleh BPJS Kesehatan dengan banyaknya kebijakan dan prosedur klaim yang harus dilengkapi oleh rumah sakit. Pada dokumen klaim BPJS Kesehatan RSUD Leuwiliang ditemukan adanya masalah kelengkapan dokumen klaim terutama pada rekapitulasi pelayanan dalam rekam 
medis dan berkas pendukung pasien yang merupakan sebagian dan kelengkapan dokumen dan prosedur klaim. Berdasarkan wawancara dengan petugas yang menangani klaim BPJS Kesehatan di RSUD Leuwiliang menunjukan beberapa masalah dalam pengajuan klaim BPJS Kesehatan antara lain: ketidak lengkapan dokumen rekam medis, dokumen klaim dan lambatnya penyerahan dokumen klaim dari ruangan rekam medis ke ruangan klaim, sehingga mempengaruhi pengajuan klaim ke BPJS Kesehatan.

\section{METODE PENELITIAN}

Penelitian ini dilakukan di RSUD Leuwiliang Kabupaten Bogor pada bulan April sampai Agustus 2019. Jenis penelitian ini merupakan penelitian kualitatif dengan menggunakan pendekatan sistem. Teknik pengumpulan data meliputi data primer melalui observasi dan wawancara mendalam dan data sekunder melalui studi kepustakaan dan telaah dokumen. Teknik yang digunakan dalam pengambilan sampel adalah purposive sampling yaitu teknik pemilihan sampel yang ditentukan oleh peneliti berdasarkan pengetahuan yang dimiliki terkait judul penelitian.

Tabel 1 Karakteristik Informan

\begin{tabular}{|c|c|c|c|c|c|}
\hline Informan & Usia & $\begin{array}{c}\text { Jabatan/ } \\
\text { Posisi }\end{array}$ & JK & Pendidikan & $\begin{array}{c}\text { Lama } \\
\text { Bekerja }\end{array}$ \\
\hline 1 & 31 tahun & Pendaftaran Rajal & P & D3 Manajemen & 9 tahun \\
\hline 2 & 22 tahun & Pendaftaran Ranap & P & SMA & 3 tahun \\
\hline 3 & 35 tahun & Pegawai Klaim/Gruper & P & D3 Keperawatan & 9 tahun \\
\hline 4 & 26 tahun & Pegawai Klaim/Gruper & L & D3 Akuntansi & 4 tahun \\
\hline 5 & 37 tahun & Pegawai klaim/Gruper & L & D3 Teknik & 9 tahun \\
\hline 6 & 45 tahun & Pegawai Klaim/Gruper & L & S1 Ekonomi & 5 tahun \\
\hline 7 & 24 tahun & Pegawai Klaim/Gruper & P & SMK & 1 tahun \\
\hline 8 & 24 tahun & $\begin{array}{c}\text { Rekam } \\
\text { Medis/Assembling }\end{array}$ & P & SMK & 5 tahun \\
\hline 9 & 35 tahun & Rekam Medis/Koder & L & D3 Rekam Medis & 5 tahun \\
\hline 10 & 29 tahun & IT Rumah Sakit & L & D3 & 4 tahun \\
\hline 11 & 27 tahun & Kasir Rajal & L & SMA & 5 tahun \\
\hline 12 & 27 tahun & Kasir Ranap & L & D3 Manajemen & 4 tahun \\
\hline
\end{tabular}

\section{HASIL PENELITIAN INPUT}

\section{A. SDM}

Hasil observasi menunjukan bahwa ketersedian SDM di RSUD Leuwiliang memiliki jumlah SDM yang cukup yang terdiri dari 6 orang petugas pendaftaran rawat jalan (4 petugas pendaftaran, 1 antrian dan 1 distribusi), 9 orang petugas pendaftaran rawat inap, 6 orang petugas klaim, 2 orang petugas casemix, 2 orang petugas assembling, 6 orang petugas IT, dan 10 orang petugas kasir ( 6 kasir rawat jalan, 2 kasir IGD, dan 2 kasir rawat inap), hanya pegawai koder yang menyatakan bahwa SDM kurang dimana hanya terdiri 3 orang petugas ( 1 koder rawat jalan dan 2 koder rawat inap). Berikut hasil kutipan wawancara yang telah dilakukan:

"SDM di bagian koding ada 3 orang, dua rawat inap, satu rawat jalan. Masih kurang"Informan 9

Berdasarkan hasil wawancara dari segi uraian beban kerja setiap karyawan menyatakan beban kerja sudah sesuai dan cukup, dimana untuk petugas pendaftaran rawat jalan uraian tugasnya membuat jaminan atau SEP BPJS, menerima pendaftaran BPJS, mengecek kelengkapan persyaratan BPJS, untuk pendaftaran rawat inap tugasnya mengecek kelengkapan persyaratan BPJS seperti (Fotocopy BPJS, KK, KTP), mengecek BPJS 
kepesertaannya aktif atau tidak, mengecek BPJS ada terkendala denda atau tidak, dan mengecek di rawatnya sesuai hak rawat atau tidak, untuk petugas assembling tugasnya menyiapkan dan memisahkan status berkas untuk ke rekam medis dan klaim, untuk petugas IT membuat jaringan internet dan memastikan pembuatan koneksi tidak terhambat dan tidak terjadi masalah dari segi jaringan internet, untuk petugas kasir tugasnya menginput tagihan hasil dari berkas-berkas pasien berobat dan tagihan berkas BPJS dan menginput pesyaratan BPJS. Hanya pegawai klaim dan koder yang menyatakan bahwa beban kerja berlebih atau overload. Dimana untuk petugas klaim uraian tugasnya adalah entri data, membuat laporan BPJS, membuat laporan bulanan, verifikasi berkas, verifikasi kodingan dan verifikasi isi resume medis, grouper, dan membuat perjalanan dinas, sedangkan uraian tugas petugas koder yaitu mengkoding isi resume berkas klaim, menelah diagnosa utama dan sekundernya dan tindakannya.

Berikut hasil kutipan wawancara yang telah dilakukan:

"sebenernya rada rada overload soalnya satu orang itu megang semuanya misalkan entry iya,gruper iya, kita bikin laporan iya terus verifikasi juga, mulai dari verifikasi berkas, terus kita juga verifikasi kodingan, kadang verifikasi isi berkas resume, jadi ya bebannya overload" Informan 3

"kita menelah mendiagnosa utamanya nanti kita koding diagnosa sekundernya sama tindakanya. tapi kalau dari segi beban kerja berlebih karna mengerjakan kodingan ganda" Informan 9

Berdasarakan hasil wawancara mendalam untuk pelatihan yang berkaitan dengan BPJS, secara umum sebagian karyawan hanya perwakilan 1 orang di setiap unit untuk mengikuti pelatihan dimana hasil dari informasi nya di beritahukan kepada anggotanya. Serta untuk dilakukannya pelatihan di setiap unit berbeda-beda.Berikut hasil kutipan wawancara yang telah dilakukan:

"ada sih tapi kadang suka buat jadi perwakilan aja ga semuanya ikut pelatihan tapi hasil dari pelatihan nanti di share informasinya ke yang lain"Informan 7

\section{B. Sarana dan Prasarana}

Berdasarkan hasil observasi dan wawancara mendalam untuk kelengkapan kebutuhan peralatan atau perlengkapan yang menunjang kerja dan proses pemberkasan klaim BPJS seperti kondisi ruang kerja, kondisi sarana dan prasarana, ketersediaan komputer, kursi petugas, meja, ruang tunggu, mesin nomor antrian, alat tulis kantor (ATK) pensil, pulpen, cuter, penggaris, steples, penghapus, tip-x, gunting, klip dan lain-lain, jaringan internet secara umum di RSUD leuwiliang sudah memadai, hanya saja untuk Sistem Informasi Manajemen Rumah Sakit (SIMRS) belum dapat dilaksanakan karena komputer satu belum terkoneksi dengan komputer yang lain. Berikut hasil kutipan wawancara yang telah dilakukan:

"SIMRS kita hanya untuk ke poli klinik saja belum sampai satu RS. Untuk ATK kita sudah cukup,wifi ada, komputer,kursi petugas,ruang tunggu, mesin nomor antrian, paling fasilias seperti meja saja yang kurang. Masih bisa digunakan. kondisi ruang kerja dari segi luas cukup" Informan 1 


\section{Dana}

Berdasarkan hasil wawancara untuk dana khusus atau insentif untuk penambahan tanggung jawab mengurus berkas disamping melakukan tugas fungsional, seluruh pegawai yang diwawancara mengatakan tidak ada intensif atau uang tambahan. Hanya pegawai koder saja yang mengatakan mendapatkan dana tambahan berupa tunjangan koder dan Jasa Pelayanan (JP). Berikut hasil kutipan wawancara yang telah dilakukan:

"ada, tapi untuk nominal saya ga bisa nyebutin ya, paling di koder kita kelebihannya dapet tunjangan koder sama JP berbeda dengan unit lainnya yang tidak dapat tunjangan mungkin hanya sebatas JP" Informan 9

\section{SOP}

Berdasarkan hasil observasi ditemukan bahwa di setiap ruangan ada yang telah memiliki SOP dimana petugas pendaftaran rawat jalan dengan nomor dokumen 005/RM/III/2016 tentang pengisian berkas rekam medis di instalasi rawat jalan terkait pengisian, memeriksa, mencatat identitas pasien maupun keluarga pasien, data status sosial, diagnosa dan pengobatan yang diberikan kepada pasien rawat jalan, SOP pendaftaran rawat inap dengan nomor dokumen 006/RM/III/2016 tentang pengisian berkas rekam medis pasien rawat inap terkait kegiatan pengisian, memeriksa, mencatat identitas pasien maupun keluarga pasien, data status sosial, diagnosa dan tindakan pengobatan yang diberikan kepada pasien rawat inap SOP petugas klaim dengan nomor dokumen Keu.SPO.38 tentang alur proses klaim dan pengajuan klaim BPJS kesehatan terkait langkah-langkah dalam penginputan data pengklaiman serta target pengiriman berkas klaim kepada pihak BPJS, SOP petugas assembling dengan nomor dokumen 020/RM/SPO tentang assembling rekam medis terkait kegiatan untuk meneliti kelengkapan formulir rekam medis yang diisi oleh tenaga kesehatan untuk menunjang mutu rekam medis, SOP petugas koder dengan nomor dokumen 021/RM/SPO tentang koding terkait kegiatan pengolahan data dalam memberikan kode dari diagnosa pasien rawat inap sesuai dengan kode dari ICD-10 dan ada yang tidak memiliki SOP yaitu petugas IT dan petugas Kasir. serta petugas yang memiliki SOP telah melaksanakan sesuai SOP yang ada. Berikut hasil kutipan wawancara yang telah dilakukan:

"SOP jelas ada karna kita kan kerja mengikuti sop nomor 021/RM/SPO tentang koding menjelaskan kegiatan pengolahan data dalam memberikan kode dari diagnosa pasien sesuai dengan kode dari ICD-10. emang sudah kewajiban jadi harus dijalankan" Informan 9

“di IT tidak ada SOP”Informan 10

"tidak ada SOP kalau di kasir mba kita hanya input saja"Informan 12

\section{Proses}

\section{A. Alur pemberkasan}

Berdasarkan hasil observasi terkait Alur Proses Pelayanan Pasien BPJS di RSUD Leuwiliang sudah cukup baik. Selain itu pasien disediakan ruang tunggu sambil menunggu nomor antrian dipanggil dan pasien sudah mengikuti alur yang sudah ditetapkan di RSUD Leuwiliang. 


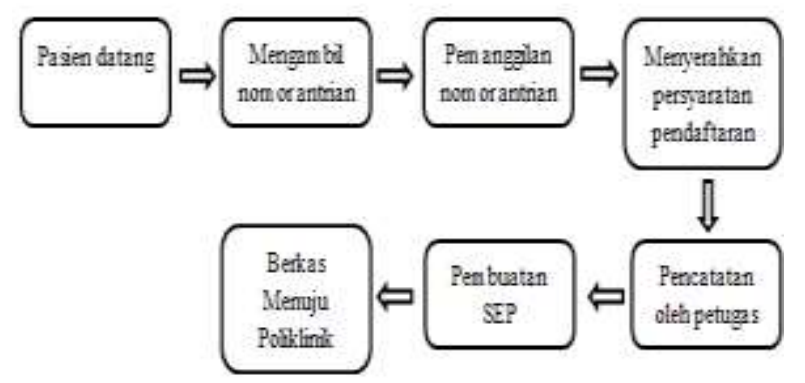

\section{Gambar 1 Alur Proses Pelayanan Pasien BPJS RSUD Leuwiliang}

Berdasarkan gambar diatas dapat diketahui bahwa alur proses pelayanan pasien BPJS di RSUD Leuwiliang adalah sebagai berikut:

1. Pasien datang mengambil nomor antrian Berdasarkan hasil observasi sebelum petugas pendaftaran memanggil pasien BPJS, terlebih dahulu pasien yang akan mendaftar diharuskan untuk mengambil nomor antrian di petugas bagian pendaftaran. Setelah mengambil nomor antrian lalu pasien akan menunggu diruang tunggu yang disediakan sambil menunggu nomor antrian dipanggil.

2. Pasien dipanggil untuk dilakukan identifikasi oleh petugas pendaftaran terkait identias pasien, pasien lama atau pasien baru, poliklinik tujuan, cara pembayaran (BPJS atau umum) dan menyerahkan persyaratan untuk pasien BPJS yaitu fotokopi kartu BPJS, KTP, KK dan surat rujukan fasilitas kesehatan tingkat pertama atau surat kontrol untuk pasien yang memang sedang melanjutkan pengobatan di RSUD Leuwiliang bila berkas lengkap dan memenuhi syarat dapat langsung memperoleh pelayanan pemeriksaan oleh dokter bisa itu dokter poliklinik atau dokter IGD. Dalam hal berkas yang dibawa oleh pasien tidak lengkap, maka bagian loket pendaftaran harus menelusuri dahulu masalahnya. Berdasarkan hasil wawancara dan observasi yang dilakukakan di tempat pendaftran rawat inap RSUD Leuwiliang diketahui bahwa jika ada pasien yang tidak mempunyai kartu BPJS petugas pendaftaran menyediakan rencana kartu BPJS, pasien akan diberikan kelonggaran 3 hari kartu BPJS tersebut diurus. Berikut hasil kutipan wawancara yang telah dilakukan:

"kalau misalkan BPJS untuk pasien di rawat inap kalau misalkan pasien dari awalnya masuk pasien kalau misalkan pasien itu sudah punya bpjs bpjs itu di cek kembali takutnya kan terkadang ada denda penunggakkan dan yang lainnya nah kalau misalkan ada denda atau penunggakkan itu harus dibayarkan terlebih dahulu sebelum bpjsnya dipakai kalau misalkan bpjsnya belum ada itu disini bisa rencana bpjs waktunya itu 3 hari eee awal dirawat pasien tapi kalau lebih dari 3 hari maka status penjaminan pasien menjadi umum"Informan 2

3. Petugas menyiapkan formulir pendaftaran lalu pasien dipersilahkan menunggu dipoliklinik tujuan. Berdasarkan hasil wawancara dan observasi diketahui bahwa selain menyusun formulir petugas pendaftran diharuskan mengecek kembali kelengkapan berkasnya. Berikut hasil kutipan wawancara yang telah dilakukan:

"untuk pemberkasan eee setelah di pendaftaran ke polikilink di poliklinik di sertakan untuk eee obat eee dan diagnosa dokter, tindakan medis dan kasih hasil penunjang diserahkan ke kami nanti kami mengecek kembali kelengkapan berkas takutnya ada 


\section{kekurangan atau hal lainnya"Informan 1}

4. Pembuatan SEP, dalam pembuatan SEP petugas diharuskan untuk memasukan nomor kartu BPJS dan diperlukan untuk melihat persyaratan yang dibawa oleh pasien.

5. Berkas diantarkan ke poliklinik tujuan Kendala dalam pemberkasan klaim adalah halhal yang menyebabkan lambatnya proses pemberkasan klaim BPJS. Berdasarkan hasil wawancara mendalam ditemukan kendala dalam pemberkasan klaim antara lain hasil penunjang (radiologi, hasil labolatorium, hasil rounsen, hasil USG, hasil EKG dll) yang tidak lengkap, berkas yang tidak lengkap, internet eror, salah koder diagnosa sama tata laksana penunjang, tulisan dokter susah dibaca, diagnosa yang tidak tertulis. Berikut hasil kutipan wawancara yang telah dilakukan:

"kalau kendala mungkin kekurangan berkas kaya hasil penunjang hasil radiologi, hasil USG hasil EKG hasil lab hasil ronsen dan sebagainya, terus salah koding, internet kadang eror"Informan 6

\section{B. Alur proses klaim}

Berdasarkan hasil wawancara terkait Alur Proses Klaim di RSUD Leuwiliang sudah cukup baik. Akan tetapi dalam pemprosesannya terdapat beberapa kendala antara lain ketidak lengkapan berkas, double berkas, jaringan internet down/eror, kesalahan pengkodingan, tulisan dokter sulit dibaca, hasil penunjang tidak lengkap sehingga akan menyebabkan keterlambatannya pemprosesan klaim dan akan mempengaruhi pengajuan klaim kepada pihak BPJS.

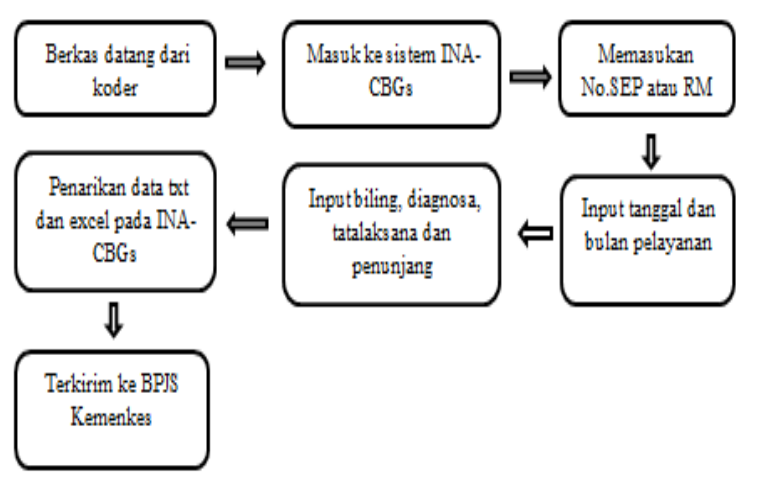

Gambar 2 Alur Proses Klaim

Berdasarkan gambar diatas dapat diketahui bahwa alur proses klaim BPJS di RSUD Leuwiliang adalah sebagai berikut:

1. Sebelum berkas diserahkan ke bagian grouper terlebih dahulu berkas berada di bagian koder untuk diberi pengokedan setelah itu baru berkas diserahkan ke bagian gruper untuk diinput ke sistem INA-CBGs.

2. Untuk penginputan ke dalam sistem INA- CBGs berkas dikelompokan terlebih dahulu berdasarkan jenis pelayanan rawat inap dan rawat jalan, lalu petugas klaim memasukan nomor SEP untuk berkas rawat jalan dan nomor RM untuk berkas rawat inap tindakan ini untuk melihat identitas nama pasien sudah sesuai atau tidak di berkas tersebut.

3. Setelah selesai melakukan penginputan nomor SEP dan nomor RM petugas memverifikasi 
berkas menginput tanggal dan bulan pelayanan serta menginput tagihan billing, diagnosa, tatalaksana dan penunjang.

4. Setelah selesai petugas melakukan penarikan data TXT dan Excel pada sistem INA-CBGs.

5. Berkas Terkirim ke BPJS Kemenkes.

6. Proses alur tersebut didapatkan dari hasil wawancara dan telaah dokumen dengan petugas gruper (klaim). Proses tersebut sesuai dengan Standart Operational Procedure tentang alur proses klaim dengan No.dokumen Keu.SPO.38 dengan prosedur sebagai berikut:

a. Berkas diserahkan ke koder untuk dilakukan pengkodingan

b. Selanjutnya berkas diserahkan ke bagian Grouper untuk diinput ke Software INA-CBGs

c. Dikelompokan berdasarkan jenis pelayanan Rawat Inap dan Rawat Jalan

d. Verifikasi berkas (tanggal dan bulan pelaynan), input billings, diagnosa, tatalaksana dam penunjang.

e. Penarikan data TXT dan Excel pada software INA-CBGs

f. Pengiriman TXT dan Excel pada verifikator BPJS

Kendala dalam pemprosesan klaim adalah hal-hal yang menyebabkan lambatnya proses klaim BPJS. Berdasarkan hasil wawancara mendalam ditemukan bahwa terdapat kendala dalam pemprosesan klaim yaitu, jaringan internet eror, ketidak lengkapan berkas, double berkas, keterlambatan berkas, salah koder, hasil penunjang tidak lengkap, tulisan dokter sulit dibaca. Berikut hasil kutipan wawancara yang telah dilakukan:

"kendalanya biasanya server eror kalau ga server eror dari kita bisa dari bagian BPJS nya, salah koder, berkas tidak lengkap, tulisan dokter susah dibaca itu sih yang sering banget terjadi jaringannya eror sampai sekarang sih masih suka eror"Informan $\mathbf{7}$

\section{Supervisi}

Supervisi yang dilakukan di RSUD Leuwiliang sebagian karyawan yang di wawancarai sudah menjalankan supervisi dari atasannya masing-masing untuk petugas pendaftaran rawat jalan dimonitoring oleh pelayanan medis (yamned) dan keuangan terkait percepatan pengisian rekam medis dan kelengkapan berkas, untuk pendaftaran rawat inap dilakukan rapat bulanan dan morning report oleh kepala instalasi terkait kelengkapan persyaratan BPJS, pengecekan status kepemilikan kartu BPJS aktif atau tidak, untuk petugas klaim diadakan rapat dan koordinasi oleh kepala bagian tata usaha (kabag TU) terkait kelengkapan berkas, ketepatan dan percepatan pengisian berkas, untuk petugas assembling diadakan rapat bulanan, untuk petugas koder diadakan rapat oleh (Kabag TU, yanmed dan keuangan) terkait Pengisian resume medis tatalaksana diagnosa dan tindakan, untuk petugas IT diadakan rapat oleh direktur terkait kelancaran server dari segi jaringan internet agar tidak ada masalah, untuk kasir diadakan rapat terkait penginputan data, akan tetapi untuk dilakukannya supervisi di setiap unit berbeda- beda atau tidak tentu. Berikut hasil kutipan wawancara yang telah dilakukan:

"Untuk dipendaftaran kita dimonitoring sama yanmed. Satu minggu sekali biasanya hari rabu. Percepatan pengisian rekam medis dan kelengkapan berkas"Informan $\mathbf{1}$ 


\section{Evaluasi}

Sistem evaluasi dapat diartikan sebagai suatu proses untuk menyediakan informasi tentang sejauh mana pencapaian suatu kegiatan, seberapa jauh dilakukannya, berapa kali dilakukannya, apa saja yang menjadi bahan evaluasi serta siapa yang berhak memberikan evaluasi tersebut. Berdasarkan hasil wawancara ditemukan bahwa sistem evaluasi di RSUD Leuwiliang seluruh karyawan yang diwawancari sudah melakukan evaluasi, karena setiap bulan di bagian unit masing-masing selalu mengadakan rapat bulanan untuk evaluasi. Dimana evaluasi yang dilakukan di bagian pendaftaran yaitu diadakannya rapat oleh direktur dan kabag TU terkait percepatan kelengkapan pengisian berkas dan pengisian hasil penunjang, untuk bagian klaim diadakan rapat dengan rekam medis casemix terkait ketidak lengkapan berkas dan isi resume medis, pengembalian berkas lama dan tulisan dokter susah dibaca, untuk bagian assembling terkait ketidak lengkapan hasil penunjang dan isi resume yang tidak tertulis, Berikut hasil kutipan wawancara yang telah dilakukan:

"evaluasinya rapat bareng sama bagian terkait rekam medis casemix. ketidak lengkapan berkas dan isi resume. Sebulan sekali. kabag TU”Informan 3

\section{Output}

Berdasarkan Telaah dokumen diketahui bahwa kebijakan yang ditetapkan oleh Rumah Sakit Umum Daerah Leuwiliang dengan nomor dokumen Keu.SPO.38 tentang dalam penyerahan dokumen kepada pihak BPJS memiliki jangka waktu atau target pengiriman. Dimana jangka waktu yang di tetapkan 15 hari kerja per bulan dan paling telat pengiriman ditanggal 10 serta berkas klaim yang dinyatakan terlambat adalah berkas yang ditagihkan kepada BPJS diatas tanggal 10 bulan berikutnya.

Berdasarkan hasil wawancara ditemukan bahwa penyebab faktor yang mempengaruhi keterlambatan pemprosesan berkas terjadi di RSUD Leuwiliang antara lain karena kurangnya hasil penunjang medis seperti radiologi, hasil labolatorium, hasil USG, Hasil CT-scan, hasil ronsen, hasil EKG dan lain-lain, tanda tangan dokter, kurangnya kelengkapan persyaratan BPJS, berkas klaim tidak lengkap, jaringan internet eror atau down, kesalahan pengisian kodingan, pengembalian berkas lama, diagnosa dokter tidak jelas, isi resume kurang dan lainlain. Berikut hasil kutipan wawancara yang telah dilakukan:

"kekurangan administrasi biasanya seperti tidak ada tanda tangan dokter tidak ada hasilhasil penunjang hasil lab, hasil USG, hasil ronsen, EKG, CT scan, interet eror, salah koding sama ketidak lengkapan berkas"Informan 1

Berdasarkan hasil wawancara mendalam pada pegawai yang merangkap sebagai grouper didapatkan bahwa pemberkasan klaim biasanya mundur. Berikut hasil kutipan wawancara yang telah dilakukan:

"biasanya kita mundur eee mulai input per bulan pelayanannya misalnya kaya sekarang yang harusnya udah ngerjain pelayanan bulan juni, tapi sekarang masih ngerjain bulan April biasanya kendalanya dari berkas yang tidak lengkap jadi kan harus dibalikin untuk di lengkapin kan itu kan memakan waktu juga, yang sering juga internetnya suka eror"

\section{Informan 7}


Telaah dokumen yang dilakukan terhadap data berkas klaim rawat jalan dan rawat inap pada bulan Januari hingga bulan Desember 2018, masih ada yang ditolak dan belum dibayarkan oleh BPJS dengan data yang ditampilan sebagai berikut:

\section{Tabel 2 Data Berkas Klaim Rawat Jalan}

\begin{tabular}{|c|c|c|c|c|}
\hline No & Bulan Pelayanan & $\begin{array}{c}\text { Berkas yang } \\
\text { Diklaim }\end{array}$ & $\begin{array}{c}\text { Berkas yang } \\
\text { dibayarkan BPJS }\end{array}$ & $\begin{array}{l}\text { Selisih } \\
\text { Berkas }\end{array}$ \\
\hline 1 & Januari2018 & 7388 & 7316 & 72 \\
\hline 2 & Februari 2018 & 7152 & 7068 & 84 \\
\hline 3 & Maret 2018 & 7973 & 7801 & 172 \\
\hline 4 & April 2018 & 7799 & 7566 & 233 \\
\hline 5 & Mei 2018 & 7652 & 7424 & 288 \\
\hline 6 & Juni 2018 & 8581 & 8486 & 95 \\
\hline 7 & Juli 2018 & 8756 & 8507 & 249 \\
\hline 8 & Agustus 2018 & 8486 & 8408 & 78 \\
\hline 9 & September 2018 & 7820 & 7747 & 73 \\
\hline 10 & Oktober 2018 & 8910 & 8848 & 62 \\
\hline 11 & November 2018 & 8718 & 8596 & 122 \\
\hline 12 & Desember 2018 & 7962 & 7904 & 58 \\
\hline \multicolumn{4}{|c|}{ Total } & 1.586 \\
\hline
\end{tabular}

Berdasarkan tabel diatas dapat diketahui bahwa sepanjang bulan pelayanan dari bulan Januari hingga bulan Desember 2018 terdapat selisih berkas, yang artinya ada dana rumah sakit yang belum dibayarkan dan masih ada yang ditolak oleh BPJS. Data yang ada menunjukan bahwa sepanjang bulan Januari hingga bulan Desember 2018 total jumlah berkas klaim BPJS rawat jalan yang ditolak adalah sebanyak 1.586 berkas klaim. Dimana selisih berkas klaim rawat jalan paling banyak adalah di bulan Mei 2018 yaitu sebanyak 288 berkas, dengan selisih klaim paling sedikit di bulan Desember 2018 yaitu sebanyak 58 berkas.

Tabel 3 Berkas Klaim Rawat Inap

\begin{tabular}{|c|l|c|c|c|}
\hline No & Bulan Pelayanan & $\begin{array}{c}\text { Berkas yang } \\
\text { diklaim }\end{array}$ & $\begin{array}{c}\text { Berkas yang } \\
\text { dibayarkan BPJS }\end{array}$ & $\begin{array}{c}\text { Selisih } \\
\text { Berkas }\end{array}$ \\
\hline 1 & Januari 2018 & 1106 & 929 & 177 \\
\hline 2 & Februari 2018 & 997 & 886 & 111 \\
\hline 3 & Maret 2018 & 1233 & 1097 & 136 \\
\hline 4 & April 2018 & 1238 & 1102 & 136 \\
\hline 5 & Mei 2018 & 1247 & 1154 & 93 \\
\hline 6 & Juni 2018 & 951 & 865 & 86 \\
\hline 7 & Juli 2018 & 1246 & 1131 & 115 \\
\hline 8 & Agustus 2018 & 1073 & 1000 & 73 \\
\hline 9 & September 2018 & 1166 & 1111 & 55 \\
\hline 10 & Oktober 2018 & 1126 & 1079 & 47 \\
\hline 11 & November 2018 & 1220 & 1032 & 188 \\
\hline 12 & Desember 2018 & 1121 & 1019 & 102 \\
\hline \multicolumn{4}{|c|}{ Total } & 1.319 \\
\hline
\end{tabular}

Berdasarkan tabel diatas dapat diketahui bahwa berkas klaim rawat inap masih serupa dengan berkas klaim rawat jalan yaitu selalu memiliki selisih berkas, antara klaim yang diserahkan dengan yang dibayarkan oleh BPJS. Data yang ada menunjukan bahwa sepanjang bulan Januari hingga bulan Desember 2018 total jumlah berkas klaim BPJS rawat inap adalah sebanyak 1.319 berkas klaim. Dimana selisih berkas klaim rawat inap paling banyak adalah di bulan November 2018 yaitu sebanyak 188 berkas, dengan selisih klaim paling sedikit di bulan Oktober 2018 yaitu sebanyak 47 berkas. 


\section{PEMBAHASAN INPUT}

\section{A. SDM}

Sumber daya manusia merupakan komponen penting yang harus ada dalam manajemen organisasi, kegiatan dalam organisasi tidak akan berjalan tanpa ada sumber daya manusia (Kaswan, 2012).

Hasil penelitian diperoleh bahwa ketersediaan jumlah SDM dinilai mempunyai jumlah SDM yang cukup memadai, yang terdiri dari 6 orang petugas pendaftaran rawat jalan (4 petugas pendaftaran, 1 antrian, 1 distribusi), 9 orang petugas pendaftaran rawat inap, 6 orang petugas klaim, 2 orang petugas assembling, 6 orang petugas IT, 10 orang petugas kasir (6 kasir rawat jalan, 2 kasir IGD, dan 2 kasir rawat inap), hanya saja pegawai koder menyatakan bahwa SDM kurang dimana hanya terdiri dari 3 orang (1 rawat jalan, 2 rawat inap). Dari segi uraian beban kerja dalam pengurusan pemberkasan klaim BPJS, setiap karyawan menyatakan bahwa beban kerja sudah cukup, hanya pegawai klaim dan koder yang menyatakan bahwa beban kerja ganda dan overload, selain itu kurangnya pelatihan untuk menambah pengetahuan yang memadai membuat pemprosesan berkas klaim menjadi terlambat. Hal ini sesuai dengan penelitian Malonda dkk (2015) menyatakan bahwa SDM merupakan salah satu faktor keterlambatan pengajuan klaim BPJS karena kurangnya kuantitas serta kualitasnya.

\section{B. Sarana dan Prasarana}

Sarana dan prasarana yang mendukung merupakan hal penting untuk pelaksanaan implementasi sebuah program. Sebuah implementasi kebijakan akan berjalan efektif jika memiliki fasilitas yang memadai (Winarno, 2012).

Hasil penelitian diperoleh bahwa kondisi sarana dan prasarana di RSUD Leuwiliang yang berhubungan dengan kebutuhan pemberkasan BPJS dinilai cukup baik, dari kelengkapan sarana prasarana di setiap unit masing-masing telah memiliki komputer yang terkoneksi internet, alat tulis yang memadai pensil, pulpen, penggaris, tip-x, penghapus, buku, steples, klip, cuter, gunting, telpon, kursi petugas, kursi tunggu, mesin nomor antrian, mesin pencetak kwitansi, cap rumah sakit, printer, scanner, mesin fotokopi. Disetiap ruangan tersedia komputer, koneksi internet, hanya Sistem Informasi Manajemen Rumah Sakit (SIMRS) belum dapat digunakan dengan optimal. Kendala pengoperasian SIMRS terletak pada masalah aplikasi/software. Kendala yang berkenaan dengan software adalah server yang seringkali down. Berdasarkan hasil observasi dinilai perlu dilakukan penataan ruang kerja, khusus nya ruang kerja pendaftaran rawat inap lahan ruang yang sempit dan ruang kerja IT yang kurang baik dari segi penataan tata letak meja yang berdempetan dengan meja yang lainnya, serta lahan ruang yang kurang luas.

Hal ini sejalan dengan penelitian yang dilakukan oleh Kurniadji (2018) yang menyatakan bahwa tata ruang yang baik meningkatkan produktifitas pegawai. Dalam proses pemberkasan hal utama yang di lakukan untuk memaksimalkan kerja adalah dengan mengimplementasikan aplikasi Sistem Informasi Manajemen Rumah Sakit (SIMRS). 


\section{Dana}

Menurut Hasibuan (2008) mengemukakan pengertian insentif adalah tambahan balas jasa yang diberikan kepada karyawan tertentu yang prestasinya diatas prestasi standar.

Hasil penelitian ini menunjukan dalam hal dana atau insentif kepada pelaksanaan proses pemberkasan tidak ada dana tambahan yang diberikan, hanya pegawai koder yang mendapatkan dana tambahan berupa tunjangan koder dan jasa pelayanan (JP). Walau idealnya terdapat uang tambahan untuk menghargai kerja tambahan para pegawai.

Hal ini sesuai dengan penelitian Wibowo (2008) yang menunjukan adanya hubungan antara insentif dengan kinerja pegawai. Insentif adalah bentuk penghargaan kepada pegawai atas besarnya pengorbanan yang mereka lakukan. Apabila karyawan tidak mendapatkan insentif pegawai tidak termotivasi untuk meningkatkan kinerja.

\section{SOP}

Menurut Moekijat (2008), standar operasional prosedur (SOP) terdiri dari serangkaian instruksi yang menggambarkan pendokumentasian dari kegiatan yang dilakukan secara berulang pada suatu organisasi maupun instansi pemerintah, dimana pekerjaan tersebut dilakukan bagaimana melakukannya, bilamana melakukannya, dan siapa yang melakukannya. Menurut Sailendra (2015) menyatakan bahwa SOP merupakan panduan yang digunakan untuk memastikan kegiatan operasional organisasi atau perusahaan berjalan dengan lancar.

Hasil penelitian diperoleh bahwa di setiap ruangan ada yang telah memiliki SOP dan ada yang tidak memiliki SOP serta petugas yang memiliki SOP telah melaksanakan sesuai SOP yang ada.

Hal ini sesuai dengan penelitian Kurniadji (2018), SOP selain menjelaskan indikatorindikator kerja idealnya ditetapkan dengan tenggat waktu yang ketat dan konsisten dijalankan. Sehingga semua SDM bekerja sesuai target/deadline yang memacu untuk meningkatkan produktifitas karyawan. Selain itu sejalan dengan penelitian yang dilakukan oleh Dewi Kartika (2014) bahwa proses pengolaan berkas klaim tidak hanya mengacu pada prosedur pelayanan dan klaim kesehatan tingkat lanjut yang ditetapkan oleh BPJS Kesehatan tetapi juga dibutuhkan SOP yang jelas disetiap unit klaim.

\section{Proses}

\section{A. Alur pemberkasan}

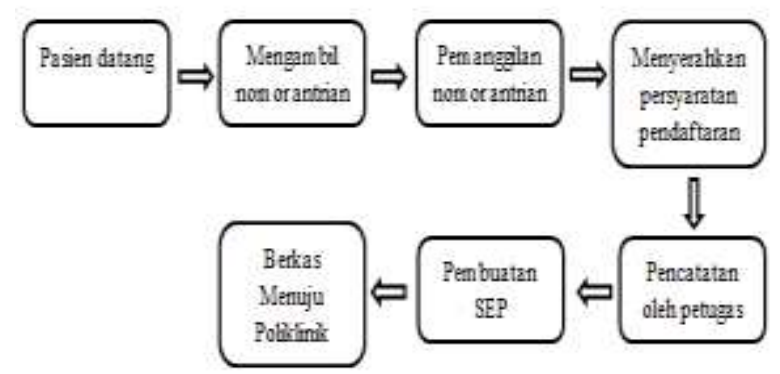

Gambar 3 Alur Proses Pelayanan Pasien BPJS RSUD Leuwiliang 
Hasil penelitian diperoleh bahwa proses pelayanan pasien BPJS dimulai dari pendaftaran diloket. Administrasi dimulai dari pengambilan nomor antrian lalu pasien akan menunggu diruang tunggu yang sudah disediakan sambil menunggu nomor antrian dipanggil. Pasien dipanggil untuk dilakukan identifikasi oleh petugas pendaftaran terkait (identitas pasien, pasien lama atau baru, poliklinik tujuan, cara pembayaran BPJS atau umum) dan menyerahkan persyaratan untuk pasien BPJS. Pasien yang membawa fotokopi BPJS, KTP, KK dan surat rujukan dari FKTP (Fasilitas Kesehatan Tingkat Pertama) yang bila berkas lengkap dan memenuhi syarat dapat langsung memperoleh pelayanan pemeriksaan oleh dokter bisa itu dokter poliklinik atau dokter IGD. Dalam hal berkas yang dibawa oleh pasien tidak lengkap, maka bagian loket pendaftaran harus menelusuri dahulu masalahnya.

Kendala dalam pemberkasan klaim adalah hal-hal yang menyebabkan lambatnya proses pemberkasan klaim BPJS. Berdasarkan hasil wawancara mendalam ditemukan kendala dalam pemberkasan klaim antara lain hasil penunjang (radiologi, hasil labolatorium, hasil rounsen, hasil USG, hasil EKG dll) yang tidak lengkap, berkas yang tidak lengkap, internet eror, salah koder diagnosa sama tata laksana penunjang, tulisan dokter susah dibaca, diagnosa yang tidak tertulis.

Hal ini sesuai dengan penelitian kurniadji (2018) menyatakan bahwa kendala-kendala yang menyebabkan lambatnya proses pemberkasan berkas yang kurang, kesalahan dalam pemberian pengkodingan. Selain itu penelitian yang dilakukan oleh Tettey, dkk (2012) bahwa ditemukan beberapa kendala dalam proses pengajuan klaim asuransi kesehatan diantaranya yaitu formulir klaim belum diisi dengan lengkap, dan kurangnnya petugas yang memiliki kompetensi.

\section{B. Alur proses klaim}

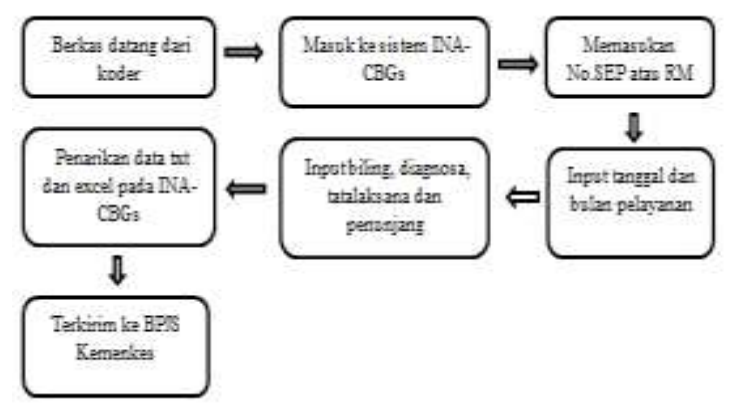

Gambar 4 Alur Proses Klaim

Hasil penelitian diperoleh bahwa Sebelum berkas diserahkan ke bagian grouper terlebih dahulu berkas berada di bagian koder untuk diberi pengokedan setelah itu baru berkas diserahkan ke bagian grouper untuk diinput ke sistem INA-CBGs. Untuk penginputan ke dalam sistem INA-CBGs berkas dikelompokan terlebih dahulu berdasarkan jenis pelayanan rawat inap dan rawat jalan, lalu petugas klaim memasukan nomor SEP untuk berkas rawat jalan dan nomor RM untuk berkas rawat inap tindakan ini untuk melihat identitas nama pasien sudah sesuai atau tidak di berkas tersebut.Setelah selesai melakukan penginputan nomor SEP dan nomor RM petugas memverifikasi berkas menginput tanggal dan bulan 
pelayanan serta menginput tagihan billing, diagnosa, tatalaksana dan penunjang. Setelah selesai petugas melakukan penarikan data TXT dan Excel pada sistem INA-CBGs. Berkas Terkirim ke BPJS Kemenkes. Berdasarkan hasil wawancara mendalam ditemukan bahwa terdapat kendala dalam pemprosesan klaim yaitu, jaringan internet eror, ketidak lengkapan berkas, double berkas, keterlambatan berkas, salah koder, hasil penunjang tidak lengkap, tulisan dokter sulit dibaca.

Hal ini serupa dengan penelitian yang dilakukan oleh Malonda, dkk (2015) keterlambatan pada pengkoderan dan pengentrian disebabkan karena jaringan internet yang kurang baik. Selain itu serupa dengan penelitian Malonda, dkk (2015) bahwa verifikasi pada dokumen klaim bertujuan untuk memastikan bahwa biaya program JKN oleh BPJS Kesehatan dimanfaatkan secara tepat jumlah, tepat waktu dan tepat sasaran.

\section{Supervisi-Evaluasi}

Supervisi-evaluasi adalah kegiatan supervisi (pembinaan dari atasan terhadap bawahan) yang dilakukan berkenaan dengan pemberkasan BPJS sampai proses evaluasi untuk melihat apakah supervisi yang diberikan telah menuai hasil yang diharapkan. Hasil penelitian diperoleh bahwa seluruh karyawan yang diwawancarai sudah menjalankan supervisi-evaluasi dari atasannya masing-masing dan mengadakan rapat bulanan untuk evaluasi, akan tetapi jangka waktu untuk dilakukannya supervisi-evaluasi di setiap unit berbeda-beda atau tidak tentu.

Hal ini sejalan dengn penelitian Kurniadji (2018), supervisi dan evaluasi yang berkala dibutuhkan dalam upaya pelaksanaan pelayanan dan pemberkasan klaim BPJS yang sesuai SOP dan target waktu. Setelah supervisi dilakukan pula evaluasi dengan memantau temuantemuan data dan berapa kasus sebagai dasar evaluasi, sehingga evaluasi terarah dan memiliki indikator keberhasilan program berdasarkan data-data dan fakta kinerja.

\section{Output}

Faktor yang mempengaruhi pemprosesan berkas terjadi di RSUD Leuwiliang antara lain karena proses melengkapi semua persyaratan klaim yang membutuhkan waktu yang relatif panjang (kelengkapan berkas klaim seperti hasil penunjang lab yang belum dilampirkan, hasil radiologi, hasil CT-Scan, hasil ronsen, hasil USG dan lain lain, tanda tangan dokter, kurangnya kelengkapan persyaratan BPJS, berkas klaim tidak lengkap, jaringan internet error atau down, kesalahan pengisian kodingan, pengembalian berkas lama, diagnosa dokter tidak jelas, isi resume kurang, beban kerja ganda, dan kurangnya pelatihan SDM. Berdasarkkan hasil wawancara mendalam pada pegawai yang merangkap sebagai grouper (klaim) didapatkan bahwa terdapat keterlambatan dalam proses penginputan berkas klaim sehingga yang seharusnya mengerjakan berkas klaim dibulan yang sekarang akan tetapi terhambat dengan penginputan berkas klaim di bulan yang lalu yang masih harus dikerjakan atau dalam penginputan klaim tidak one tap service sehingga mempengaruhi keterlambatan pengajuan proses pengklaiman.

Penyebab lambatnya proses pemberkasan seperti yang disebutkan diatas serupa dengan penelitian Dewi Kartika (2014) tentang ketepatan waktu penyelesaian klaim menyebutkan bahwa jumlah SDM belum sebanding dengan beban kerja, kurangnya pengetahuan dan 
pengalaman SDM dalam menggunakan sistem IN-CBGs. Malonda, dkk (2015) menyebutkan dalam penelitiannya bahwa pengajuan klaim sering terlambat disebabkan karena dokumen tidak lengkap dan waktu penyetoran yang lambat sehingga sehingga mempengaruhi pada proses koding dan entri data serta verifikasi.

\section{KESIMPULAN}

Berdasarkan hasil penelitian kualitatif dengan teknik observasi, wawancara dan telaah data, mengenai Analisis Faktor yang Mempengaruhi Proses Klaim BPJS Di RSUD Leuwiliang Bogor Tahun 2018 dapat di ambil beberapa kesimpulan. Kesimpulan tersebut di dapatkan sebagai berikut:

1. Input

Kesimpulan dalam penelitian ini adalah sebagai berikut:

1. SDM untuk pelayanan di RSUD Leuwiliang sudah cukup, namun beban kerja yang ganda. SDM untuk tim casemix sudah ada namun pekerjaan terlimpahkan pada satu orang sehingga penginputan klaim menjadi lama. Pelatihan SDM masih kurang.

2. Sarana dan prasarana di RSUD Leuwiliang sudah baik yang terdiri dari komputer yang terkoneksi internet, kursi, meja, ruang tunggu, telpon, mesin nomor antrian, mesin pencetak kwitansi, cap rumah sakit, printer, scanner, mesin fotokopi, dan alat tulis kantor yang memadai pensil, pulpen, penggaris, tip-x, pengahapus, buku, steples, klip, cuter, gunting.

3. Namun kelengkapan berkas membutuhkan waktu yang lama karna tidak one tap service, dimana SIMRS belum berjalan maksimal sehingga berdampak pada berkas klaim.

4. Tidak ada dana tambahan atau insentif kepada karyawan berkenaan dengan penambahan beban kerja.

5. SOP bagian petugas pendaftaran, petugas klaim, dan petugas rekam medis (assembling dan koder) telah memiliki SOP dan sudah melakukan tugas sesuai dengan SOP yang ada, akan tetapi untuk bagian kasir dan IT belum memiliki SOP.

2. Proses

1. Alur pemberkasan sudah berjalan dengan baik namun masih ada beberapa kendala seperti hasil penunjang (radiologi, hasil labolatorium, hasil rounsen, hasil USG, hasil EKG dll) yang tidak lengkap, berkas yang tidak lengkap, internet eror, salah koder diagnosa sama tata laksana penunjang, tulisan dokter susah dibaca, diagnosa yang tidak tertulis.

2. Alur proses pengklaiman sudah berjalan dengan baik namun masih ada beberapa kendala dalam penginputan proses klaim antara lain jaringan internet eror, ketidak lengkapan berkas, double berkas, keterlambatan berkas, salah koder, hasil penunjang tidak lengkap, tulisan dokter sulit dibaca.

3. Supervisi-Evaluasi di RSUD Leuwiliang sudah menjalankan dari atasan masing- masing, akan tetapi jangka waktu untuk dilakukannya Supervisi-Evaluasi di setiap unit berbedabeda atau tidak tentu.

3. Output

Diketahui sepanjang bulan Januari hingga bulan Desember 2018 terdapat selisih berkas klaim yang artinya ada dana rumah sakit yang belum dibayarkan dan masih ada yang ditolak oleh BPJS. Total jumlah berkas klaim BPJS rawat jalan yang ditolak adalah sebanyak 1.586 berkas 


\section{DAFTAR PUSTAKA}

Anggrainatingai, Virgo. (2013). Faktor - Faktor Keterlambatan Pengembalian Rekam Medis Pasien Rawat Inap di Rumah Sakit DKT Dr.Soetarto Yogyakarta: Universitas Gadjah Mada.

Ayuningtyas, Dumilah, Misnaniarti Misnaniarti, Siti Khodijah Parinduri, Fitria Aryani Susanti,

$\mathrm{Ni}$ Nyoman Dwi Sutrisnawati, and Sayyidatul Munawaroh. "Local Initiatives In Preventing Coronavirus Based On Health Policy Perceptive." Journal of Indonesian Health Policy and Administration 5, no. 2 (2020).

Ayuningtyas,D., Parinduri,S. K.dan Susanti, F. A. 2018. Integritas Kepemimpinan Antikorupsi di Sektor Kesehatan.Jurnal Integritas 4(1): 5.

Asnifatima A, Parinduri SK, Aligori A. (2020). Risiko dan Karakteristik Penderita Toksoplasmosis berdasarkan Demografi, Keberadaan Hewan Peliharaan, Hygiene dan Sanitasi. Heart, Jurnal Kesehatan Masyarakat,8(X), 41-49.

A Nasution, A Maulana, D Kurniawan. (2019). BERSAMA MEMAJUKAN DESA. Abdi Dosen: Jurnal Pengabdian Pada Masyarakat 3 (2), 99-104

B. Rizki, D. Fitriana, R. Hidana, S.K. Parinduri, Analisis Penerapan Sistem Informasi Manajemen Puskesmas (Simpus) dengan Model Human Organization Technology (HOT)-Fit di Puskesmas Tanah Sareal Kota Bogor Tahun 2019 Pendahuluan Metode, PROMOTOR: Jurnal Mahasiswa Kesehatan Masyarakat 3(1) (2020) 18-27.

Chotimah, I., Oktaviani, S., \& Madjid, A. (2018). Evaluasi Program Tb Paru Di Puskesmas Belong Kota Bogor Tahun 2018. PROMOTOR, 1(2), 87-95.

Chotimah, I., Anggraini, D. (2018). Pemberdayaan Masyarakat Melalui Peningkatan Kualitas Pendidikan, Ekonomi, Kesehatan Dan Lingkungan. ABDIDOS 2 (1), 62-72.

Chotimah, I. (2017). Gambaran Perilaku Merokok Mahasiswa Universitas Ibn Khaldun Bogor 2013. HEARTY 5 (1).

Dewi, Kartika (2014). Analisis Ketepatan Waktu Penyelesaian Klaim Rawat Inap Pasien BPJS di RSUD Dr.Adjidarmo Kabupaten Lebak.

Fitrianingtyas, Pertiwi, dan Rachmania, W. Faktor-Faktor yang Berhubungan dengan Kejadian Kurang Energi Kronis (KEK) pada Ibu Hamil di Puskesmas Warung Jambu Kota Bogor. HEARTY Jurnal Kesehatan Masyarakat. 2018;6(2):1-8.

Hasibuan, 2008. Manajemen Sumber Daya Manusia. Jakarta: PT Bumi

Jogiyanto. (2005). Pengertian Sistem. Andi. Yogyakarta Dikutip Pada Tanggal 7 Februari 2019

Kaswan. (2012). Manajemen Sumber Daya Manusia Untuk Keunggulan Bersaing Organisasi.Yogyakarta: Graha Ilmu.

Kurniadji, (2018). Analisa Faktor Yang Mempengaruhi Keterlambatan Pemrosesan Klaim BPJS di RSUD Mampang Prapatan Kota Administrasi Jakarta Selatan DKI Jakrta: Tesis

Malonda, dkk. (2015). Analisis Pengajuan Klaim BPJS Kesehatan di RSUD Dr.Sam Ratulangi Tonando Manado: Universitas Sam Ratulangi

Moekijat, M. (2008) Penerapan Produktivitas dalam Organisasi. Jakarta: Bumi Aksara Noviatri, wahyu . (2016). Analisis Faktor Penyebab Keterlambatan Penyerahan Klaim BPJS di RS Panti Nugroho: Jurnal Kesehatan Vokasional , Oktober 2016, Vol,1 No.1.

Peraturan Mentri Kesehatan Republik Indonesia Nomor 71 Tahun 2013 Tentang Pelayanan 
Pada Jaminan Kesehatan Nasional

Peraturan Presiden Republik Indonesia Nomor 12 Tahun 2013 Tentang Jaminan

Peraturan Pemerintah Nomor 101 tahun 2012 tentang Penerima Bantuan Iuran Jaminan Kesehatan

Peraturan Mentri Kesehatan Republik Indonesia Nomor 52 Tahun 2016Tentang Standar Tarif Pelayanan Kesehatan Dalam Penyelenggaraan Program Jaminan Kesehatan

P. S. Akbar, S. K. Parinduri, and R. Hidana, “Gambaran Pelaksanaan Surveilans Epidemiologi Di Rumah Sakit Umum Daerah Leuwiliang Kabupaten Bogor Tahun 2018," PROMOTOR, vol. 2, no. 5, pp. 410-421, 2019.

Pertiwi, F. D., Hariansyah, M., \& Prasetya, E. P. (2019). FAKTOR RISIKO STUNTING PADA BALITA DIKELURAHAN MULYAHARJA TAHUN 2019. PROMOTOR, 2(5). https://doi.org/10.32832/pro.v2i5.2531

Pertiwi, F. D., Rahman, R. M., \& Lestari, D. W. (2018). Pemberdayaan masyarakat melalui bidang literasi di Desawaru Jaya. Jurnal ABDI DOSEN: Jurnal Pengabdian Pada Masyarakat, 2(2), 129-137. https://doi.org/10.32832/abdidos.v2i2.170

Sailendra, Annie. 2015. Langkah-Langkah Praktis Membuat SOP. Trans Idea Publising: Jogjakarta.

Tettey, dkk (2012). Challenges In Provider Payment Under The Ghana National Health Insurance Scheme: A Case Study Of Claims Management In Two Districts Ghana Medical Journal, Volume 46, Number 4.

Undang - Undang Republik Indonesia No.24 Tahun 2011 Tentang Badan Penyelenggaraan Jaminan Sosial

Undang-UndangNomor 40 Tahun 2004 tentang Sistem Jaminan Sosial Nasional (SJSN)

Wibowo. (2008). Manajemen Kinerja.Jakarta. Penerbit: Rajagrafindo Persada

Winarno. (2012). Kebijakan Publik Teori, Proses, dan Studi Kasus. Yogyakarta:CAPS. 